\title{
( Relationship between Socio-Demographic aßBe Characteristics and Job Satisfaction: Evidence from Private Bank Employees
}

\author{
Md. Mostafijur Rahman*1, Md. Razwan Hasan Khan Chowdhury², Md. Amirul Islam ${ }^{3}$, Mst. Ummay Tohfa ${ }^{4}$ \\ Md. Abdul Kader ${ }^{5}$, Alim Al Ayub Ahmed ${ }^{6}$, Praveen Kumar Donepudi ${ }^{7}$ \\ ${ }^{1}$ Department of Business Administration, First Capital University of Bangladesh, Alamdanga Road, Chuadanga-7200, BANGLADESH \\ 2,5 Department of Sociology, First Capital University of Bangladesh, Alamdanga Road, Chuadanga-7200, BANGLADESH \\ ${ }^{3,4}$ Department of English, First Capital University of Bangladesh, Alamdanga Road, Chuadanga-7200, BANGLADESH \\ ${ }^{6}$ School of Accounting, Jiujiang University, Jiujiang, Jiangxi, CHINA \\ ${ }^{7}$ Enterprise Architect, Information Technology, UST-Global, Inc., Ohio, USA
}

\begin{abstract}
In this competitive business world satisfied employee is the prime asset of any business organization as an employee's satisfaction can ensure continuous growth. The purpose of this study was to find out, is there any significant relationship between socio-demographic characteristics and job satisfaction of private bank employees in Bangladesh? By using Yamane's formula the study consisted of 56 (male 89.3\% and female $10.7 \%$ ) respondents and it used semi-structured questionnaires containing pre-coded and open-ended questions. All questions were rated with the Likert 5-point scale. As all the variables used in this study (both dependent and independent) were categorical, the Chi-square test was used to assess the relationship. In this study, significant relations were found between some demographic characteristics, such as, sex, age, salary, and family income with job satisfaction indicators which were participation in decision making, training facilities, and increase knowledge and capacity. Education and geographic location did not show any significant relationship with job satisfaction indicators. Around $92.5 \%$ of male employees reported that the current organization helped to increase their knowledge and working capacity $(\mathrm{p}<0.028)$. More than half of the employees $(55.3 \%)$ of the $30-35$ age group could not take part in decision making $(\mathrm{p}<0.013)$. In addition, family income and salary also exerted significant associations with participation in decision-making and proper training facilities respectively. Several stakeholders and concern authorities should give top priority in these demographic areas while developing strategies to improve the job satisfaction level of employees.
\end{abstract}

Keywords: Job Satisfaction, Chi-Square Test, Demographic Characteristics, Private Bank Employees, Bangladesh

\section{INTRODUCTION}

Job satisfaction has significant impact on employee's wellbeing both in individual and amassed level and also foster productivity. Ultimately, a nation's economic prosperity largely influenced by job satisfaction. Employees' turnover intentions, absenteeism, and performance are highly depending on it as dissatisfaction cause lethargy and cut organizational commitment (Nadinloyi et al., 2013). Satisfied employees are more committed to both organization and occupation and usually do not leave job. Employees with more satisfaction are more productive and they are the key resource of competitive advantage for any business organization and higher performance from employees as well as organizational success depends on job satisfaction (Judge et al., 2010).While employees' job satisfaction is the key of the performance, productivity, turnover intention of an organization, employees' satisfaction toward job depends on designation, group culture, relations between managers and peers, physical and social environment, management style, organizational justice, reward, work itself, pray and promotion. On the other hand, a study in Lebanon revealed that dissatisfaction occurs due to less opportunity in decision 
making, bad relationship with authority, low salaries and benefits, less job security, poor recognition and congested scheduling. It also associated to emotional exhaustion and burnout.

The effect of job dissatisfaction is that it increases the cost of recruitment, selection and training, discourages the current employees and reduces the growth of organization. Extensive research proved that job satisfaction did not happen in isolation, as it depends on organizational variables such as structure, size, pay, and leadership, working conditions, clear staffing policy and channels of communication, participation in decision making, security and good governance (Peterson, 1995; Khan et al., 2020). Job satisfaction is an emotional pleasant and positive status which is resulting from the job assessment or job experience of an individual. Locke (1976) defined job satisfaction "as a pleasurable or positive emotional state which is the result of the appraisal of one's job experiences" (Locke, 1976).

Since banking institutions are the backbone of a nation's economy (Jindal, \& Gupta, 2016) and play a vital role for the overall economic development (Rahman et al. 2017), so the effective management of human resources and maintenance of higher job satisfaction levels are important to run the banks properly (Jindal, \& Gupta, 2016; Azad et al., 2011). Bangladesh is a developing country and banking sector has significant contribution in the development process (Rahman et al. 2017). Banking sector bought dramatic changes in agriculture, business and other sectors which have brought higher employment opportunities, increases in income level, and changes in consumption pattern. In addition, with the expansion of private banking business, along with customized services, has created a severe implied competition in this sector (Uddin \& Kabir, 2015). This competition has made the service gap wider as private banks offer better services to their internal and external customers (Islam \& Islam, 2014; Ahmed, 2020). As better services of banks depend on employees (Donepudi, 2017), job satisfaction is one of the most widely researched areas in organization behavior and human resource management (Opkara, 2002).

\section{LITERATURE REVIEW}

Satisfaction ensures employees high self-confidence, which lifts their performance (Bogler and Somech, 2004). Human resource policies are positively related with human capital development (Ahmed, 2015). Irani (2002) conducted a study to the University of Florida's agricultural communications program to assess how satisfied respondents were with their jobs, as well as explore the relationships between facets of job satisfaction and graduates' perceptions as to the effectiveness of their educational preparation. Results of the study indicated that the majority of respondents were generally satisfied with their positions. Rahman et al. (2017) found female employees were more satisfied than males. Khan et al.
(2012) revealed that pay, promotion, job safety and security, working conditions, job autonomy, relationship with co-workers, and relationship with supervisor and nature of work affect the job satisfaction and performance. Bae and Yang (2017) showed receiving maternity and child care leave is positively associated with job satisfaction whereas child care subsidy did not show a significant effect on satisfaction. A study by Jiang et al. (2016) found that role clarity, formalization, and perceived promotional opportunities were significant predictors of the satisfaction and distributive justice, and procedural justice has often been found to be predictors of job satisfaction in the United States.

DeTienne et al. (2012) Showed moral stress is statistically responsible for increasing employee fatigue and turnover and decreasing job satisfaction. Rahman et al. (2017) revealed low level of job satisfaction was associated with age, designation, salary, marital status, service period and working environment. Hossain (2014) revealed that working conditions, pay, fairness, and promotion significantly influenced employee job satisfaction in Bank but individual factors such as age and gender did not. Anjom et al. (2016) have found that because of smart remuneration, attracts the compensation package, dignity, smooth career growth, job security, pension funds, provident fund, gratuity, incentives, and lots of other benefits fresh graduates have a fascination for banking sector jobs in Bangladesh.

Ahmed (2015) revealed that recruitment \& selection, training \& development, salary \& benefits, and reward have a positive effect on employees' job satisfaction whereas supervisory role and job security have an adverse effect. Uddin et al. (2016) conducted a study on the employees of the general insurance companies in Bangladesh and found that pay and promotional potential, well-organized chain of command and general working condition have positive relationship with job satisfaction where poor team spirit and poor job security have negative relation.

\section{Methodology}

There are 7 private banks are operating in Chuadanga and all the 7 banks have been selected for this study. We included Mercantile Bank Ltd., Dutch-Bangla Bank Ltd., Islami Bank Bangladesh Ltd., Shajalal Islami Bank Ltd, First Security Islami Bank Ltd., BRAC Bank Ltd. and United Commercial Bank Ltd banks in our study.

The cross-sectional study sample consisted of 56 (male 50 and female 6) bank employee's respondents. They were interviewed from $1^{\text {st }}$ January to $26^{\text {th }}$ February, 2020.

A semi-structured questionnaire was developed using job satisfaction forces to which the respondents were asked to react using a three Bipolar scale ranging which was (i) Yes (ii) No and (iii) No comment. 


\section{Sample Size}

This study used Yamane (1967) formula to calculate sample size. Yamane (1967) provided a simplified formula to calculate sample size.

Equation is-

$\mathrm{n}=\frac{N}{1+N\left(e^{2}\right)}$

Where

$\mathrm{n}=$ is the sample size

$\mathrm{N}=$ is the population

$1=$ is a constant

$\boldsymbol{e}^{2}=$ is the estimated standard error which is $5 \%$ for $95 \%$ confidence level

$\mathrm{n}=\frac{66}{1+66\left(0.05^{2}\right)} \quad=56.65 / 56$

Dependent variables: We used several dependent variables, which were categorical, such as Gender, age, family income, salary, education and geographic location in this study (see table 1).

Independent variables: To measures the associations between demographic characteristics and job satisfaction indicators five (5) independent variables were used which were categorized decoratively. The independent variables were 'Participation in decision making', 'Availability of tools and resources', 'Training facilities', 'Gender discrimination' and 'Opportunity of increasing knowledge \& capacity'.

\section{AnALysis AND Results}

SPSS 22.0 and Excel have been used to process and analyze the data. Dependent and independent variables were analyzed by using Chi-square test. As all the variables used in this study (both dependent and independent) were categorical and to measure the relationship between categorical variables Chi-Square test fit best. That is why this study used Chi-Square test. It has been used to test the statistical significance of the parameters at $5 \%$ level. The written consent has been taken from the respondents. This study is approved by the research authority of the First Capital University of Bangladesh.

Table 1 showed the socio-demographic characteristics of the employee. Among the employees, $89.3 \%$ were male, $46.4 \%$ belonged to $30-35$ age group, $91.1 \%$ was master degree holder and Muslim, $42.9 \%$ working as training assistant officer /assistant officer /junior officer /assistant officer cash, $30.4 \%$ withdraw monthly salary between 26,000 and 35,000 , and more than $45,000,76.8 \%$ were married, $64.3 \%$ employees live in semi urban area, $42.9 \%$ service period $<36$ month.
Table 1: Socio-demographic characteristic of bank employees

\begin{tabular}{|c|c|c|}
\hline Variables & Number & $(\%)$ \\
\hline \multicolumn{3}{|l|}{ Gender } \\
\hline Male & 50 & 89.3 \\
\hline Female & 6 & 10.7 \\
\hline \multicolumn{3}{|c|}{ Age of the respondents (in years) } \\
\hline$<30$ & 18 & 32.2 \\
\hline $30-35$ & 26 & 46.4 \\
\hline$>35$ & 12 & 21.4 \\
\hline \multicolumn{3}{|c|}{ Religion of the respondents } \\
\hline Islam & 51 & 91.1 \\
\hline Hindu & 5 & 8.9 \\
\hline \multicolumn{3}{|c|}{ Education of the respondents } \\
\hline Honors degree & 5 & 8.9 \\
\hline Master's degree & 51 & 91.1 \\
\hline \multicolumn{3}{|c|}{ Designation of the respondents } \\
\hline $\mathrm{TAO} / \mathrm{AO} / \mathrm{JO} / \mathrm{ACO}^{1}$ & 24 & 42.9 \\
\hline Officer & 15 & 26.8 \\
\hline SO/PO/EO/Grade- ii $^{2}$ & 9 & 16.1 \\
\hline SPO/SEO/Grade-i ${ }^{3}$ & 8 & 14.2 \\
\hline \multicolumn{3}{|l|}{ Salary of the respondents } \\
\hline$\leq 2500$ & 12 & 21.4 \\
\hline $25,001-35,000$ & 17 & 30.4 \\
\hline $35,001-45,000$ & 10 & 17.8 \\
\hline$>45,000$ & 17 & 30.4 \\
\hline \multicolumn{3}{|c|}{ Family member of the respondents } \\
\hline$<<3$ & 17 & 30.4 \\
\hline 4 & 16 & 28.5 \\
\hline$>4$ & 23 & 41.1 \\
\hline \multicolumn{3}{|c|}{ Marital status of the respondents } \\
\hline Married & 43 & 76.8 \\
\hline Unmarried & 13 & 23.2 \\
\hline \multicolumn{3}{|c|}{$\begin{array}{lll}\text { Geographic } & \text { location } & \text { of } \\
\text { respondents }\end{array}$} \\
\hline Rural & 5 & 8.9 \\
\hline Semi- Urban & 36 & 64.3 \\
\hline Urban & 15 & 26.8 \\
\hline \multicolumn{3}{|c|}{ Family income of the respondents } \\
\hline$<45000$ & 17 & 30.4 \\
\hline $45000-65000$ & 19 & 33.9 \\
\hline$>65000$ & 20 & 35.7 \\
\hline \multicolumn{3}{|c|}{ Service period of the respondents } \\
\hline$<36$ & 24 & 42.9 \\
\hline $36-60$ & 16 & 28.5 \\
\hline$>60$ & 16 & 28.6 \\
\hline \multicolumn{3}{|l|}{ Working Environment } \\
\hline Participative & 31 & 55.4 \\
\hline Autonomy & 25 & 44.6 \\
\hline
\end{tabular}

${ }^{1=}$ Training Assistant Officer/Assistant Officer/Junior

Officer/Assistant Officer Cash

${ }^{2}=$ Senior Officer/Principal Officer/Executive Officer/Grade- ii

${ }^{3}=$ Senior Principal Officer/ Senior Executive Officer/Grade-i 
Table 2: Association between job satisfaction indicators and Sex

\begin{tabular}{|l|c|c|c|}
\hline \multicolumn{1}{|c|}{ Variables } & \multicolumn{2}{c|}{ Sex } & P Value \\
\hline Availability of Tools and Resources & & & \\
\hline No & $24(88.9 \%)$ & $3(11.1 \%)$ & 1.00 \\
\hline Yes & $26(89.7 \%)$ & $3(10.3 \%)$ & \\
\hline Participation in decision & & & \\
\hline No & $35(92.1 \%)$ & $3(7.9 \%)$ & .374 \\
\hline Yes & $15(83.3 \%)$ & $3(16.7 \%$ & \\
\hline Training facilities & & & .223 \\
\hline No & $23(95.8 \%)$ & $1(4.2 \%)$ & \\
\hline Yes & $27(84.4 \%)$ & $5(15.6 \%)$ & .319 \\
\hline Gender discrimination & & & \\
\hline No & $36(85.7 \%)$ & $6(14.3 \%)$ & \\
\hline Yes & $14(100 \%)$ & $0(0.0 \%)$ & .028 \\
\hline Increase knowledge \& Capacity & & & \\
\hline No & $1(33.3 \%)$ & $2(66.7 \%)$ & \\
\hline Yes & $49(92.5 \%)$ & $4(7.5 \%)$ & \\
\hline
\end{tabular}

Table 3: Association between job satisfaction indicators and Age

\begin{tabular}{|c|c|c|c|c|}
\hline \multirow[t]{2}{*}{ Variables } & \multicolumn{3}{|c|}{ Age } & \multirow[t]{2}{*}{ P Value } \\
\hline & $<30$ & $30-35$ & $>35$ & \\
\hline \multicolumn{5}{|l|}{ Availability of Tools \& Resources } \\
\hline No & $9(33.3 \%)$ & $13(48.1 \%)$ & $5(18.5 \%)$ & 0.877 \\
\hline Yes & $9(31.0 \%)$ & $13(44.8 \%)$ & $7(24.1 \%)$ & \\
\hline \multicolumn{5}{|l|}{ Participation in decision } \\
\hline No & $13(34.2 \%)$ & $21(55.3 \%)$ & $4(10.5 \%)$ & 0.013 \\
\hline Yes & $5(27.8 \%)$ & $5(27.8 \%)$ & $8(44.4 \%)$ & \\
\hline \multicolumn{5}{|l|}{ Training facilities } \\
\hline No & $8(33.3 \%)$ & $13(54.2 \%)$ & $3(12.5 \%)$ & 0.346 \\
\hline Yes & $10(31.3 \%)$ & $13(40.6 \%)$ & $9(28.1 \%)$ & \\
\hline \multicolumn{5}{|l|}{ Gender discrimination } \\
\hline No & $12(28.6 \%)$ & $22(52.4 \%)$ & $8(19.0 \%)$ & 0.302 \\
\hline Yes & $6(42.9 \%)$ & $4(28.6 \%)$ & $4(28.6 \%)$ & \\
\hline \multicolumn{5}{|l|}{ Increase knowledge \& Capacity } \\
\hline No & $2(66.7 \%)$ & $1(33.3 \%)$ & $0(0.0 \%)$ & 0.373 \\
\hline Yes & $16(30.2 \%)$ & $25(47.2 \%)$ & $12(22.6 \%)$ & \\
\hline
\end{tabular}

Table 4: Association between job satisfaction indicators and Education

\begin{tabular}{|l|c|c|c|}
\hline \multicolumn{1}{|c|}{ Variables } & \multicolumn{2}{c|}{ Education } & P Value \\
\hline Availability of Tools and Resources & Honors & Master & \\
\hline No & & & 0.664 \\
\hline Yes & $3(11.1 \%)$ & $24(88.9 \%)$ & \\
\hline Participation in decision & $2(6.9 \%)$ & $27(93.1 \%)$ & 1.0 \\
\hline No & & & \\
\hline Yes & $4(10.5 \%)$ & $34(89.5 \%)$ & 0.153 \\
\hline Training facilities & $1(5.6 \%)$ & $17(94.4 \%)$ & \\
\hline No & $4(16.7 \%)$ & & 1.0 \\
\hline Yes & $1(3.1 \%)$ & $31(83.3 \%)$ & \\
\hline Gender discrimination & & & \\
\hline No & $4(9.5 \%)$ & $38(90.5 \%)$ & 1.0 \\
\hline Yes & $1(7.1 \%)$ & $13(92.9 \%)$ & \\
\hline Increase knowledge \& Capacity & & & \\
\hline No & $0(0.0 \%)$ & $3(100.0 \%)$ & \\
\hline Yes & $5(9.4 \%)$ & $48(90.6 \%)$ & \\
\hline
\end{tabular}


According to table 2 around $92.5 \%$ male employees reported that the current organization helped to increase their knowledge and working capacity $(\mathrm{p}<0.028)$. On the contrary around $66.7 \%$ female recorded that they have very little opportunity which can increase their knowledge and working capacity. Table 3 showed that more than half employees $(55.3 \%$, ) of 30-35 age group could not take part in decision making where around $44.4 \%$ employees of more than 35 age group can participate $(\mathrm{p}<0.013)$. In table 4 , we did not find any significant relationship between education and job satisfaction indicators. Although Availability of tools and resources were closed.

Table 5: Association between job satisfaction indicators and Salary

\begin{tabular}{|l|c|c|c|c|c|}
\hline \multicolumn{1}{|c|}{ Variables } & \multicolumn{4}{c|}{ Salary } & P Value \\
\hline Availability of Tools and Resources & $\leq 2500$ & $25,001-35,000$ & $35,001-45,000$ & $>45000$ & \\
\hline No & & & & & \\
\hline Yes & $6(22.2 \%)$ & $9(33.3 \%)$ & $5(18.5 \%)$ & $7(25.9 \%)$ & 0.915 \\
\hline Participation in decision & $6(20.7 \%)$ & $8(27.6 \%)$ & $5(17.2 \%)$ & $10(34.5 \%)$ & \\
\hline No & & & & & \\
\hline Yes & $11(28.9 \%)$ & $15(39.5 \%)$ & $7(18.4 \%)$ & $5(13.2 \%)$ & 0.000 \\
\hline Training facilities & $1(5.6 \%)$ & $2(11.1 \%)$ & $3(16.7 \%)$ & $12(66.7 \%)$ & \\
\hline No & & & & & \\
\hline Yes & $7(29.2 \%)$ & $11(45.8 \%)$ & $4(16.7 \%)$ & $2(8.3 \%)$ & 0.011 \\
\hline Gender discrimination & $5(15.6 \%)$ & $6(18.8 \%)$ & $6(18.8 \%)$ & $15(46.9 \%)$ & \\
\hline No & & & & & \\
\hline Yes & $10(23.8 \%)$ & $14(33.3 \%)$ & $6(14.3 \%)$ & $12(28.6 \%)$ & 0.510 \\
\hline Increase knowledge \& Capacity & $2(14.3 \%)$ & $3(21.4 \%)$ & $4(28.6 \%)$ & $5(35.7 \%)$ & \\
\hline No & & & & & \\
\hline Yes & $1(33.3 \%)$ & $1(33.3 \%)$ & $1(33.3 \%)$ & $0(0.0 \%)$ & 0.658 \\
\hline
\end{tabular}

From table 5, we found that employees who withdrew highest salary $(66.7 \%)$ could participate in decision making $(\mathrm{p}<0.000)$ and around $46.9 \%$ got proper training facility.
But employees were those whose salary were in between 25,001-35,000 (39.5\%) could not take part in decision making and around $45.8 \%$ did not get proper training.

Table 6: Association between job satisfaction indicators and Geographic Location

\begin{tabular}{|c|c|c|c|c|}
\hline \multirow[t]{2}{*}{ Variables } & \multicolumn{3}{|c|}{ Geographic Location } & \multirow[t]{2}{*}{ P Value } \\
\hline & Rural & Semi- Urban & Urban & \\
\hline \multicolumn{5}{|c|}{ Availability of Tools and Resources } \\
\hline No & $2(7.4 \%)$ & $20(74.1 \%)$ & $5(18.5 \%)$ & 0.326 \\
\hline Yes & $3(10.3 \%)$ & $16(55.2 \%)$ & $10(34.5 \%)$ & \\
\hline \multicolumn{5}{|l|}{ Participation in decision } \\
\hline No & $4(10.5 \%)$ & $25(65.8 \%)$ & $9(23.7 \%)$ & 0.669 \\
\hline Yes & $1(5.6 \%)$ & $11(61.1 \%)$ & $6(33.3 \%)$ & \\
\hline \multicolumn{5}{|l|}{ Training facilities } \\
\hline No & $4(16.7 \%)$ & $16(66.7 \%)$ & $4(16.7 \%)$ & .108 \\
\hline Yes & $1(3.1 \%)$ & $20(62.5 \%)$ & $11(34.4 \%)$ & \\
\hline \multicolumn{5}{|l|}{ Gender discrimination } \\
\hline No & $4(9.5 \%)$ & $25(59.5 \%)$ & $13(31.0 \%)$ & 0.417 \\
\hline Yes & $1(7.1 \%)$ & $11(78.6 \%)$ & $2(14.3 \%)$ & \\
\hline \multicolumn{5}{|c|}{ Increase knowledge \& Capacity } \\
\hline No & $0(0.0 \%)$ & $1(33.3 \%)$ & $2(66.7 \%)$ & 0.267 \\
\hline Yes & $5(9.4 \%)$ & $35(66.0 \%)$ & $13(24.5 \%)$ & \\
\hline
\end{tabular}

In table 6, it has been found that there was no significant association between job satisfaction indicators and geographic location. But training facilities $(p=0.108)$ was close to significance level. 
Table 7: Association between job satisfaction indicators and Family Income

\begin{tabular}{|c|c|c|c|c|}
\hline \multirow[t]{2}{*}{ Variables } & \multicolumn{3}{|c|}{ Family Income } & \multirow[t]{2}{*}{ P Value } \\
\hline & $<45000$ & $45000-65000$ & $>65000$ & \\
\hline \multicolumn{5}{|c|}{$\begin{array}{l}\text { Availability of Tools and } \\
\text { Resources }\end{array}$} \\
\hline No & $9(33.3 \%)$ & $10(37.0 \%)$ & $8(29.6 \%)$ & 0.657 \\
\hline Yes & $8(27.6 \%)$ & $9(31.0 \%)$ & $12(41.4 \%)$ & \\
\hline \multicolumn{5}{|l|}{ Participation in decision } \\
\hline No & $14(36.8 \%)$ & $16(42.1 \%)$ & $8(21.1 \%)$ & 0.004 \\
\hline Yes & $3(16.7 \%)$ & $3(16.7 \%)$ & $12(66.7 \%)$ & \\
\hline \multicolumn{5}{|l|}{ Training facilities } \\
\hline No & $9(37.5 \%)$ & $11(45.8 \%)$ & $4(16.7 \%)$ & 0.035 \\
\hline Yes & $8(25.0 \%)$ & $8(25.0 \%)$ & $16(50.0 \%)$ & \\
\hline \multicolumn{5}{|l|}{ Gender discrimination } \\
\hline No & $15(35.7 \%)$ & $13(31.0 \%)$ & $14(33.3 \%)$ & 0.318 \\
\hline Yes & $2(14.3 \%)$ & $6(42.9 \%)$ & $6(42.9 \%)$ & \\
\hline \multicolumn{5}{|c|}{ Increase knowledge \& Capacity } \\
\hline No & $1(33.3 \%)$ & $2(66.7 \%)$ & $0(0.0 \%)$ & 0.343 \\
\hline Yes & $16(30.2 \%)$ & $17(32.1 \%)$ & $20(37.7 \%)$ & \\
\hline
\end{tabular}

Table 7 illustrated that employees whose family income were higher than others around $66.7 \%$ of them had the opportunity to part in decision making, in contrast, employees, whose family income were between 45000-6500 around $42.2 \%$ of them could not participate in decision making and $45.8 \%$ did not have proper training facilities.

\section{Discussion}

The work discovered significant co-relation between sociodemographic variables (Sex, Age, Salary and Family Income) with job satisfaction indicators (increase knowledge \& capacity, participation in decision and training facilities). Although, education and geographic location did not show any significant relation with job satisfaction indicators. Our study is consistent with other studies, such as, Heidarian et al. (2015) in Iran, found significance relation between demographic characteristics, for example, age, marital status, gender, higher status and years of service, and motivational factors, such as, advancement, recognition, responsibility, education and development, interpersonal relations, equity, pay, job security, recognition, attractiveness of job supervision, organizational policies, working conditions. Tabatabaei et al. (2013) revealed that there was a correlation between a few demographic variables, for example, like sex, age, education and with few organizational factors, such as, jobs situation, work shifts and hours. Azad et al. (2011) conducted a study to investigate the effects of demographic factors, job satisfaction and locus of control on organizational commitment of records management personnel in Nigerian private universities. And he found that job satisfaction, the locus of control and all the demographic factors (i.e. gender, age, marital status, education and job tenure) were positively related to organizational commitment. Mehrad et al. (2015) showed opposite result where his study revealed that demographic characteristics gender has no significant relation to job satisfaction indicators namely pay, work, promotion, and co-worker.

This study showed that sex has significance relation with the opportunity of increasing capacity and knowledge. Different studies showed different outcomes such as, Rahman et al. (2017) revealed that male is more satisfied than their female counterpart considering the indicators, such as salary, bank's sympathetic view, bonus, reward, working with colleagues, leave rules, job security, appraisal and evaluation and working schedule and satisfied workers are tending to improve knowledge and capacity. Mehrad et al. (2015) illustrated there was a significant relationship between supervision as one of the dimensions of job satisfaction and sex. Robbins and Judge (2009) claimed that sex affect some variables such as job satisfaction, turnover, and performance, Nasir et al. (2011) shown that gender and education moderated the relationship between job satisfaction and task performance, Heidarian et al. (2015) found female employees had little opportunity to participate in goal setting and decision making. Rahim (1982) showed that females were more satisfied than males when income, age, and education were controlled through covariance. Income and age positively affected job satisfaction when sex, marital status, and job categories were controlled through covariance. Rana (2015) inferred that male and female workers have a significantly different level of job satisfaction. Zou (2015) reported opposite scenario that Women, either in full-time or part-time employment, report significantly higher levels of job satisfaction than men where Rast and Tourani (2012) and Ali and Akhter (2009) found that there is no significant difference between male and female employees' job satisfaction. 
This study also presented age is significantly associated with participation in decision making. Altimus Jr. and Tersine (1973) revealed that younger workers were found to be significantly lower in satisfaction with work itself, esteem, self-actualization, and total work satisfaction. The perceptions and satisfaction level of young blue-collar workers were quite different from their older counterparts. Heidarian et al. (2015) found that job satisfaction indicators like as attractiveness of job, working condition, supervision and organization policies were significantly associated with age. Robbins and Judge (2009) revealed that age had an effect on performance, job satisfaction and turnover. Curtis (2008) illustrated that nurses under the age of 35 were less satisfied than those over the age of 36. Nasir et al. (2011) shown that age and tenure did not moderate the relationship between job satisfaction and task performance. Rahman et al. (2017) showed that employees of 30-35 age groups had low levels of job satisfaction. Job satisfaction increases with age. Why age has a positive relation to job satisfaction? Gibson and Klein (1970) showed the reasons; first, older people seem to have a different relationship to authority than younger people. Second, they have higher needs to be directed and to accept orders, and third, cognitive structures are different from those of younger people. Bae (2008) revealed different result that laborers older than 60 years had a low job satisfaction.

In our study, we have found salary and family income have a significant association with participation in decision making and training facilities. Heidarian et al. (2015) showed salary and education have a significant association. Michael (2003) found that good family support reduces individuals' negative experiences at work. Asadullah et al. (2019) said that compensation is the major element that affects the employee performance. Judge et al. (2010) illustrated pay level is only marginally related to satisfaction. Mahnaz et al. (2013) showed that the employees who receive more salaries have more job satisfaction. But Young et al. (2014) showed a surprising result which was salary has a negative relationship to both job and life satisfaction.

\section{LIMITATIONS OF THE STUDY}

The main limitation of this study is small sample size. Some employees denied giving information which may limit our study. We consider only private bank's employee which is another limitation. However, it represented a clear picture of associations between demographic characteristics and job satisfaction among employee in Bangladesh.

\section{Conclusion And Recommendation}

The purpose of this study was to explore the significant relationships between demographic characteristics and job satisfaction among private bank employees in Bangladesh and the result hit the objective. This study revealed significant associations between demographic characteristics, such as, sex, age, salary and family income and job satisfaction indicators which were participation in decision, training facilities and increase knowledge and capacity. This finding will help the policy maker to formulate new strategies and also to revise the existing one to ensure employees satisfaction toward their job. To prompt employee's satisfaction more strategies could be developed such as employees should be given the opportunity to participate in decision making, fixing working hour, transparency, equitable and competitive compensation and promotion system, ensuring effective training and development program, removing gender discrimination. More research on job satisfaction is essential to formulate the strategy to keep the employees satisfied with their job.

\section{REFERENCES}

Ahmed, A. A. A. (2020). Corporate Attributes and Disclosure of Accounting Information: Evidence from the Big Five Banks of China. Journal of Public Affairs. e2244. https://doi.org/10.1002/pa.2244

Ahmed, A. A. A., Asadullah, A. B. M., \& Rahman, M. M. (2016). NGO's Financial Reporting and Human Capital Development. American Journal of Trade and Policy, 3(2), 53-60. https://doi.org/10.18034/ajtp.v3i2.401

Ahmed, R. U. (2015). A comparative research on job satisfaction and human resource management practices: Empirical investigation of few commercial bank employees in Bangladesh. International Journal of Human Resource Studies 5: 290-300.

Ali, T., \& Akhter, I. (2009). Job Satisfaction of Faculty Members in Private Universities -In Context of Bangladesh. International Business Research 2: 167-175.

Altimus Jr, C. A., \& Tersine, R. J. (1973). Chronological age and job satisfaction: The young blue-collar worker. Academy of Management 16: 53-66.

Anjom, W., Akther, S., \& Karim, A. M. (2016). Factors affecting the fascination for banking sector jobs in Bangladesh: An empirical study conducted among the fresh graduates in Chittagong. Australasian Journal of Business, Social Science and Information Technology 2: 216-224.

Asadullah, A., Juhdi, N. B., Islam, M. N., Ahmed, A. A. A., \& Abdullah, A. (2019). The Effect of Reinforcement and Punishment on Employee Performance. ABC Journal of Advanced Research, 8(2), 47-58. https://doi.org/10.18034/abcjar.v8i2.87

Azad, M. R., Khan, W. \& Ahmed, A. A. A. (2011). HR Practices in Banking Sector on Perceived Employee Performance: A Case of Bangladesh. Eastern University Journal, 3(3), 30-39. http://doi.org/10.5281/zenodo.4043334

Bae, K. B., \& Yang, G. (2017). The Effects of Family-Friendly Policies on Job Satisfaction and Organizational Commitment: A Panel Study Conducted on South Korea's Public Institutions. Public Personnel Management 46: 1-17.

Bae, K. J. (2008). The analysis of change in job satisfaction. Labor Review 40: 84-95.

Bogler. R., \& Somech, A. (2004). Influence of teacher empowerment on teachers' organizational commitment, professional commitment and organizational citizenship behavior in schools. Teach Teach Educ. 20(3):277-89. 
Curtis, E. A. (2008). The effects of biographical variables on job satisfaction among nurses. British journal of nursing 17: 174-80.

DeTienne. K. B., Phillips, J. C., Agle, B. R., \& Ingerson, M. C. (2012). The Impact of Moral Stress Compared to Other Stressors on Employee Fatigue, Job Satisfaction, and Turnover: An Empirical Investigation. J Bus Ethics. 110:377391. https://doi.org/10.1007/s10551-011-1197-y

Donepudi, P. K. (2017). Machine Learning and Artificial Intelligence in Banking. Engineering International, 5(2), 83-86. https://doi.org/10.18034/ei.v5i2.490

Gibson, J. L., \& Klein, S. M. (1970). Employee attitudes as a function of age and length of service: A re-conceptualization. Academy of Management Journal 13:411-425.

Heidarian, A. R., Kelarijani, S. E. J., Jamshidi, R., \& Khorshidi, M. (2015). The relationship between demographic characteristics and motivational factors in the employees of social security hospitals in Mazandaran. Caspian J Intern Med 6: 170-174.

Hossain, M. S. (2014). Job satisfaction of bank employees in Bangladesh. Research Journal of Finance and Accounting 5: 1-8.

Irani, T. (2002). Job satisfaction as an outcome measure of the effectiveness of an agricultural communications academic program. Journal of Agricultural Education, 43: 12-23.

Islam, M. S., \& Islam, M.M. (2014). A comparative study of job satisfaction in banking. A case study of public and private bank sectors. European Journal of Business and Management, 6: 105-111.

Jiang, S., Lamberteg, E. G., Jin, D. Z. X., \& Xiang, S. M. (2016). Effects of work environment variables on job satisfaction among community correctional staff in china. Criminal Justice and Behavior 43: 1450 -1471.

Jindal, M., \& Gupta, N. (2016). A case study of HDFC Bank: Measuring employee empowerment using demographics. International Journal of Latest Technology in Engineering, Management \& Applied Science -IJLTEMAS V: 17-24.

Judge, T. A., Piccolo, R. F., Podsakoff, N. P., \& Rich, B. L. (2010). The relationship between pay and job satisfaction: A meta-analysis of the literature. Journal of Vocational Behavior 77: 157-167.

Khan, A. H., Nawaz, M. M., Aleem, M., \& Hamed, W. (2012). Impact of job satisfaction on employee performance: An empirical study of autonomous Medical Institutions of Pakistan. African Journal of Business Management 6: 2697-2705.

Khan, W., Ahmed, A. A. A., Hossain, M. S., Neogy, T. K. (2020). The Interactive Approach to Working Capital Knowledge: Survey Evidence. International Journal of Nonlinear Analysis and Applications, 11(Special Issue), 379-393. https://doi.org/10.22075/ijnaa.2020.4631

Locke, E. A. (1976). The Nature and Causes of Job Satisfaction. In: Dunnette MD (ed.), Hand book of Industrial and Organizational Psychology, Rand McNally, Chicago, IL, pp: 1297-1343.

Mahnaz, M. A., Mehdi, M., Jafar, K. M., \& Abbolghasem, P. (2013). The effect of demographic characteristics on organizational citizenship behavior in the selected teaching hospitals in Tehran. African Journal of Business Management 7: 3324-3331.

Mehrad, A., Hamsan, H. H. B., Redzuan, M. B., \& Abdullah, H. (2015). The effect of gender on job satisfaction of academic staff in Malaysian public universities. Journal of Educational, Health and Community Psychology 4: 2088-3129.
Michael, F. R. (2003). Work-Family Balance. In: Quick JC, Tetrick LE, editors. Handbook of Occupational Heahh Psychology. Washington DC: American Psychological Association.

Nadinloyi, K. B., Sadeghi, H., \& Hajloo, N. (2013). Relationship between Job Satisfaction and Employees Mental Health. Procedia - Social and Behavioral Sciences 84:293 - 297.

Nasir, R., Fatimah, O., Mohammadi, M. S., Wan Shahrazad, W. S, Khairudin, R., \& Halim, F. W. (2011). Demographic variables as moderators in the relationship between job satisfaction and task performance. Pertanika Journal of Social Science and Humanities 19: 33-40.

Opkara, J. O. (2002). The impact of salary differential on managerial job satisfaction: A study of the gender gap and its implications for management education and practice in a developing economy. The Journal of Business in Developing Nations 8: 65-92.

Peterson, W. (1995). The effects of organizational design on group cohesiveness power utilization and organizational climate. Unpublished Master's Thesis, University of South Africa, Pretoria.

Rahim, A. (1982). Demographic variables in general job satisfaction in a hospital: A multivariate study. Perceptual and Motor Skills 55: 711-719.

Rahman, M., Ashraf, A., Hasan, N., Hoshen, S., Chowdhury, R. H. K., \& Moni, M. A. (2017). Job Satisfaction Levels among Employees of Private Commercial Banks at Chuadanga District in Bangladesh. Journal of Business \& Financial Affairs 6:1-8.

Rana, M. S. (2015). Job satisfaction effecting factors of employees in Bangladesh banking sector. International Journal of Economics, Finance and Management Sciences 3: 352-357.

Rast, S., \& Tourani, A. (2012). Evaluation of employees' job satisfaction and role of gender difference: An empirical study at airline industry in Iran. International Journal of Business and Social Science 3: 91-10.

Robbins, S. P., \& Judge, T. A. (2009). Organizational behavior. 13th ed. Upper Saddle River, N.J.: Prentice Hal.

Tabatabaei, S., Ghaneh, S., Mohaddes, H., \& Khansari, M. M. (2013). Relationship of job satisfaction and demographic variables in parsceram factory employees in Iran. 3rd World Conference on Psychology, Counselling and Guidance. Procedia - Social and Behavioral Sciences. 84:1795-1800.

Uddin, M. J., Chowdhury, M. M., Yasmin, M., \& Akter, A. (2016). Job satisfaction of the employees of the general insurance companies in Bangladesh. Global Disclosure of Economics and Business 5: 7-18.

Uddin, M. K., \& Kabir, M. J. (2015). Satisfaction towards banking profession: A comparative study on male and female executives. IIUC STUDIES 12: 127-138.

Yamane, T. (1967). Statistics an Introductory Analysis. 2nd Edition, New York, Harper and Row.

Young, L., Milner, M., Edmunds, D., Pentsil, G., \& Broman, M. (2014). The tenuous relationship between salary and satisfaction. Journal of Behavioral Studies in Business 7: 1-9

Zou, M. (2015). Gender, work orientations and job satisfaction. Work, employment and society, 29(1), 3-22.

$$
--0-
$$

